\title{
Analisis Tingkat Akurasi Uji Pemadatan dengan Pendekatan Numerik Berbasis Elemen Hingga
}

\author{
DEDI RAHDIANATA, INDRA NOER HAMDHAN
}

\author{
Jurusan Teknik Sipil, Fakultas Teknik Sipil dan Perencanaan \\ Institut Teknologi Nasional \\ Email: dedirahdianataipa3@gmail.com
}

\begin{abstract}
ABSTRAK
Penelitian ini membahas tentang simulasi model pemadatan antara uji laboratorium dibandingkan lapangan menggunakan PLAXIS 2D 2017 berbasis elemen hingga. Simulasi model kedua pengujian tersebut dilakukan dengan variasi beban energi yang sama untuk membandingkan perbedaan hasilnya. Simulasi model pemadatan di lapangan dilakukan dengan variasi beban, siklus dan tebal lapis pemadatan, sedangkan di laboratorium hanya variasi beban energi dan tebal lapis pemadatan berdasarkan berat isi kering. Hasil uji pemadatan berat isi kering di laboratorium sebesar 1,546 kN/ $\mathrm{m}^{2}$, sedangkan hasil simulasi model sebesar 1,6 $\mathrm{kN} / \mathrm{m}^{2}$, sehingga tingkat akurasi perbedaannya sebesar 3,49\%. Simulasi model pemadatan lapangan dengan variasi beban pada tebal lapis pemadatan yang sama menunjukan bahwa semakin besar beban pemadatan akan menghasilkan jumlah lintasan (siklus) lebih sedikit, sehingga dapat disimpulkan bahwa semakin tebal lapis pemadatan nilai penurunannya akan semakin besar.
\end{abstract}

Kata Kunci: simulasi model analisis pemadatan, pemadatan laboratorium dan lapangan, tebal lapis pemadatan, nilai penurunan.

\begin{abstract}
This research studied compaction modelling between laboratory simulation test and field test using PLAXIS 2D 2017 based on finite element method. Each tests was carried out with the same energy variations to compare the discrepancy of the result. A model with the variation in load energy, cycle and thickness of compaction layer was made to simulate the field test, while for the laboratory test, only variation in load energy and thickness of compaction layer is used based on dry unit weight. The results of the laboratory compaction test of dry unit weight was $1.546 \mathrm{kN} / \mathrm{m}^{2}$, while the model simulation were $1.6 \mathrm{kN} / \mathrm{m}^{2}$. So the accuracy difference between both is $3.49 \%$. Simulation of field model with variations in load at the same thickness of compaction layer shows that the greater load of compaction will produced less number of cycles. It can be concluded that the thicker compaction layer will increased settlement value.
\end{abstract}

Keywords: compaction model analysis, field and laboratory compaction, thickness compaction and settlement. 


\section{PENDAhUlUAN}

Indonesia merupakan negara berkembang yang sedang melakukan pembangunan infrastruktur jalan. Tujuan dalam penyediaan prasarana dan sarana jalan adalah untuk menghubungkan daerah-daerah yang tertinggal, terpencil dan sulit dicapai, sehingga diharapkan dapat meningkatkan kesejahteraan rakyat khususnya dalam bidang ekonomi. Pembangunan infratruktur jalan erat kaitannya dengan pemadatan lapangan maupun laboratorium. Permasalahan utama yang sering terjadi dalam kegagalan pelaksanaan pemadatan di lapangan diakibatkan desain pemadatan yang dirancang di laboratorium tidak sesuai dengan kondisi lapangan serta prosedur pelaksanaannya tidak sesuai dengan standar yang berlaku, sehingga menimbulkan masalah penurunan. Untuk menentukan tingkat akurasi pelaksanaan pemadatan lapangan maupun laboratorium dilakukan simulasi model menggunakan pendekatan numerik berbasis elemen hingga. Pada penelitian ini membahas tentang simulasi model pemadatan antara uji laboratorium dibandingkan lapangan menggunakan PLAXIS 2D 2017 berbasis elemen hingga.

\section{KAJIAN PUSTAKA}

\subsection{Pemadatan Tanah}

Pemadatan tanah adalah suatu proses memadatnya partikel tanah sehingga terjadi pengurangan volume udara dan volume air dengan memakai cara mekanis (Wesley, 1977). Menurut Wesley (1977) tujuan dalam melakukan pemadatan diantaranya:

1. Menaikan kuat geser tanah.

2. Memperkecil kompresibilitas dan daya rembasan air atau memperkecil pori antar ruang udara dan tanah.

3. Mengurangi permeabilitas.

4. Mengurangi besarnya penurunan ketika pasca kontruksi.

5. Memperkecil pengaruh air terhadap tanah.

6. Mengurangi permeabilitas.

7. Meningkatkan kekakuan tanah dasar maupun timbunan.

Pemadatan dibagi menjadi dua jika berdasarkan pengujiannya, diantaranya :

\subsubsection{Pemadatan Laboratorium}

Uji laboratorium umumnya digunakan untuk mendapatkan berat kering unit pemadatan maksimum dan kadar air optimum disebut tes pemadatan Proctor (Proctor, 1933). Prosedur untuk melakukan tes jenis ini dijelaskan di bagian berikut:

1. Standard Proctor Test.

2. Modified Proctor Test.

Berikut rumus yang digunakan yang kaitannya dengan pemadatan untuk jenis pemadatan modified maupun proctor:

$$
\gamma_{d}=\frac{\gamma}{(1+w)}
$$

halmana:

$\begin{array}{ll}\gamma_{d} & =\text { berat isi kering }\left[\mathrm{gr} / \mathrm{cm}^{3}\right], \\ \gamma & =\text { berat isi basah }\left[\mathrm{gr} / \mathrm{cm}^{3}\right], \\ w & =\text { kadar air }[\%] .\end{array}$

$$
\gamma_{Z A V}=\frac{\gamma \cdot G_{S}}{\gamma_{w}+\frac{w \cdot G_{S}}{S_{r}}}
$$


halmana:

ZAV = zero air void (Kondisi Kadar Udara $=0$ ),

$\gamma_{W}=$ berat isi air $\left[1 \mathrm{gr} / \mathrm{cm}^{3}\right]$,

$G_{s} \quad=$ berat jenis butiran tanah.

$$
E=\frac{h . P . n}{\frac{1}{5} \cdot V_{\text {mold }} \times 100 \%}
$$

halmana:

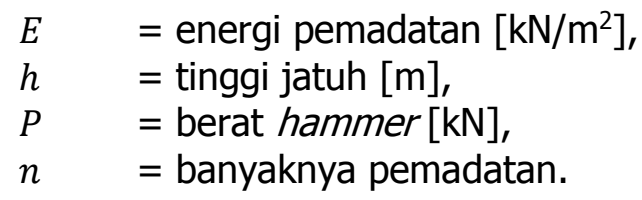

\subsubsection{Pemadatan Lapangan}

Pemadatan Lapangan dilakukan dilapangan langsung dengan angka skala besar. Berikut faktor-faktor yang mempengaruhi proses pemadatan di lapangan:

1. Pengaruh Ketebalan Interval Tiap Layer.

Menurut Howeedy et al (1975) melakukan pemadatan di lapangan untuk pasir halus bergradasi rendah, ketebalan tiap layer yang digunakan diantara $140 \mathrm{~mm}$ sampai dengan $300 \mathrm{~mm}$.

2. Siklus Pemadatan.

Menurut Howeedy et al (1975) dalam eksperimen lapangannya mendapatkan hasil bahwa pemadatan akan berbanding lurus dengan banyaknya lintasan pemadatan (siklus) yang dilakukan.

3. Pengaruh Kecepatan Pemadatan.

Menurut Seligh et al (1977) dalam pengujiannya kenaikan kecepatan memberikan pengaruh yang besar terhadap penurunan pemadatan dan pengaruh yang kecil terhadap kekakuan tanah

4. Pengaruh dari Beban.

Menurut Howeedy et al(1975), beban sangat berpengaruh terhadap hasil dari pemadatan ditandai dengan adanya peningkatan kerapatan relatif. Beban menghasilkan tegangan dan regangan.

5. Pengaruh dari Alat

Pemadatan yang dilakukan untuk tanah timbunan di lapangan menggunakan alat yang sesuai dengan jenis tanahnya. berikut alat-alat berat yang diapaki dalam proses pemadatan di lapangan:

1. Smoot Wheel Roller

2. Pneumatic Rubber Tired Roller

3. Sheep Foot Roller

4. Vibratory Roller

6. Pengaruh dari Jenis Tanah

Pengaruh dari jenis tanah sebenarnya sebagian besar sudah dijelaskan di atas, bahwa jenis tanah salah satunya mempengaruhi alat yang digunakan. berikut metode untuk mengukur kepadatan tanah di lapangan:

1. Sand Cone

2. Rubber Ballon

3. Nuclear Density Method 


\subsection{PLAXIS 2D 2017 (Finite Element Method)}

PLAXIS adalah program yang berbasis pada elemen hingga yang telah dikembangkan dengan tujuan untuk analisis permasalahan-permasalahan teknis pada bidang geoteknik. Nodul-nodul yang muncul setelah di mesh akan dijadikan sebagai acuan nantinya dalam menyeldiki daya dukung tanah di daerah tersebut. Sehingga akan didapatkan daya dukung yang berada dalam daerah yang ditinjau untuk keperluan penelitian. Dalam merampungkan mesh, cluster dibagi menjadi 2 pilihan elemen segitiga yaitu terdapat pilihan 15 elemen node dan 6 elemen node

\section{Gambar 1.}

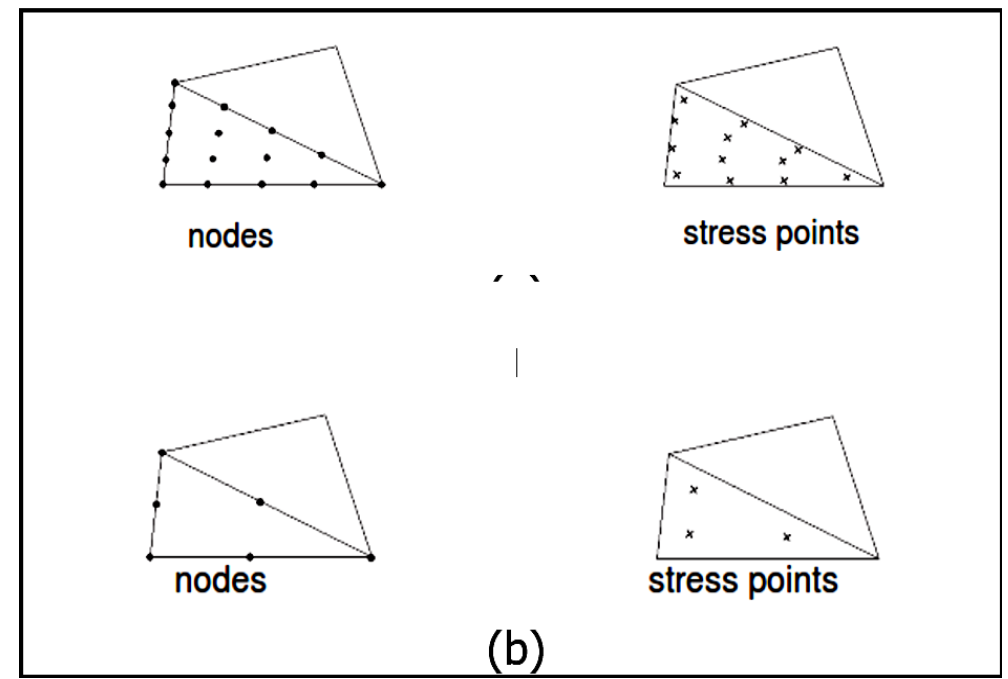

Gambar 1. Konfigurasi titik dan tegangan leleh pada tanah (a) 15 Node; (b) 6 Node

\section{Metode Elemen Hingga dan Model Material}

Metode elemen hingga adalah proses perhitungan secara numerik yang dipakai untuk mendapatkan pendekatan dari permasalahan yang kaitannya dengan masalah teknik Model material yang digunakan dalam penelitian ini diantaranya:

1. Mohr Couloumb

Mohr Couloumb menggunakan parameter kekakuan tanah, dan kekakuan tanah merupakan perbandingan dari tegangan dan regangan. Model mohr coulomb memiliki bentuk tegangan-regangan yang tidak bisa berubah ke bentuk asalnya. Kondisi tegangan yang dinyatakan oleh titik-titik yang berada di bawah bidang leleh, perilaku dari titik titik tersebut akan sepenuhnya elastis dan seluruh regangan dapat kembali seperti semula

2. Hardening soil dan Hardening soil small.

Hardening soil (HS) dan Hardening soil (HS) small model adalah model tingkat lanjutan untuk mesimulasikan perilaku beberapa tipe tanah, baik itu tanah lunak maupun tanah keras (Schanz, 1998). Pada Hardening Soil model batasan parameter yang digunakan tidak berbeda jauh dengan mohr couloumb seperti sudut geser tanah $(\varphi)$, kohesi $(c)$, dan diltancy angle $(\Psi)$, namun HS dengan HS Small dijelaskan jauh lebih akurat dibandingkan dengan Mohr-Coloumb karena menggunakan 3 parameter kekakuan: triaxial stiffness $\left(E_{50}\right)$, triaxial unloading stiffness $\left(E_{u r}\right)$ dan oedometer loading stiffness $\left(E_{\text {oed }}\right)$. Hal ini akan menghasilkan hasil yang berbeda dengan model mohr couloumb ataupun yang lainnya.

Perbedaan model Hardening soil dan Hardening soil small yaitu terdapat pada menganalisi mengenai penurunan yang terjadi. Hardening soil small lebih cocok digunakan untuk penurunan yang relatif kecil. 


\section{METODOLOGI PENELITIAN}

\subsection{Tahapan Penelitian}

\subsubsection{Tinjauan Pustaka}

Penilitian yang telah dilakukan mengacu pada literatur-literatur yang berkaitan dengan pembahasan. Berbagai pengertian dan percobaan yang telah dilakukan oleh tokoh yang berpengaruh dijadikan acuan dalam penulisan penelitian, seperti Terzagi, Joseph, Braja, dan lain sebagainya. Bagan alir penelitian ini disajikan pada Gambar $\mathbf{2}$ di bawah ini.

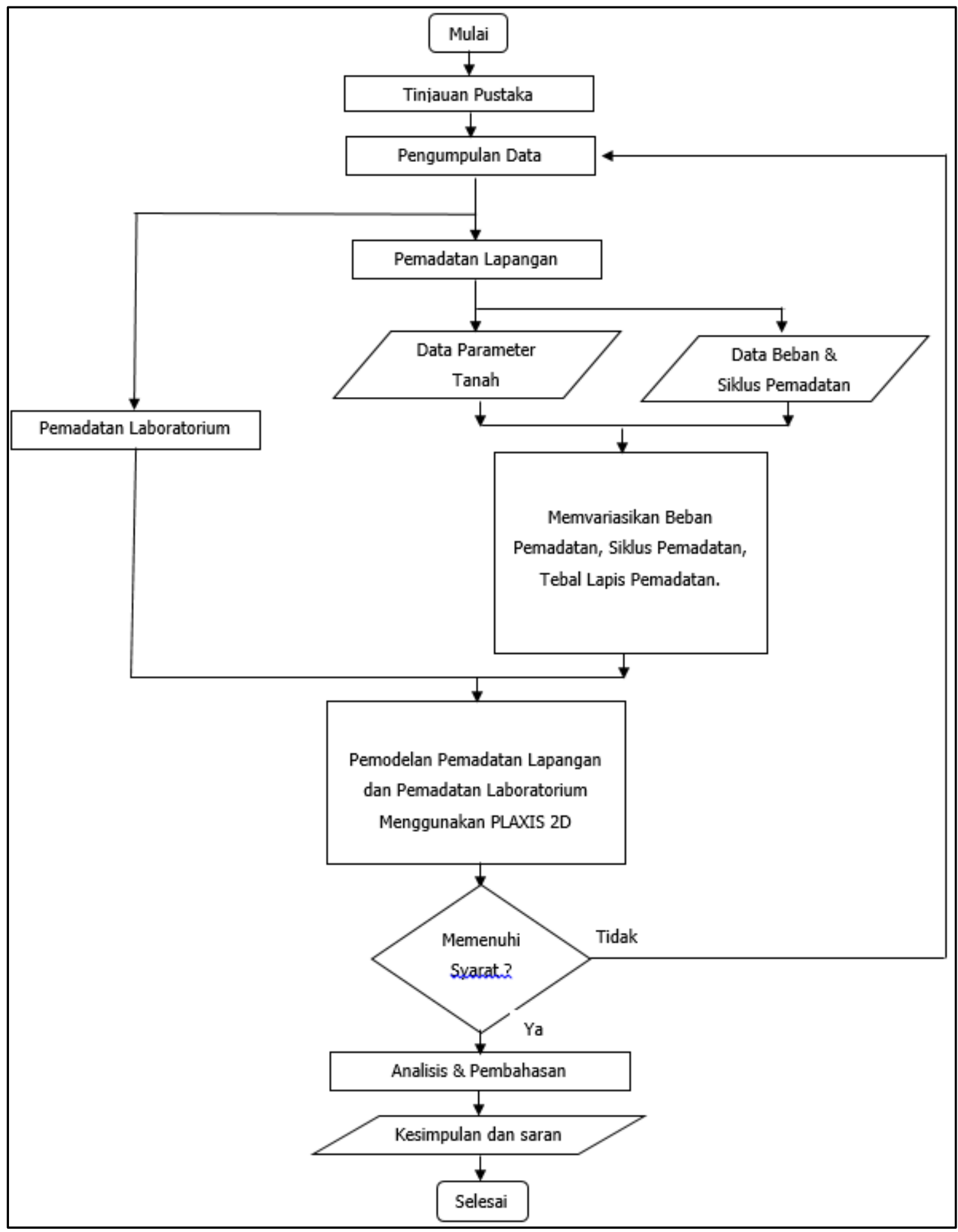

Gambar 2. Bagan alir penelitian

RekaRacana: Jurnal Teknik Sipil - 91 


\subsubsection{Pengumpulan Data}

Data tanah yang digunakan untuk pemadatan Laboratorium maupun data Lapangan merupakan data dari Proyek Jalan Tol Plumbon Cirebon. Pemadatan Laboratorium dengan memvariasikan energi pemadatan sedangkan pemadatan Lapangan memvariasikan beban dan tebal lapis pemadatan sehingga nantinya akan mendapatkan hasil jumlah lintasan untuk pemadatan di Lapangan.

\subsubsection{Simulasi Model dengan Pemodelan PLAXIS 2D 2017}

Pemadatan Laboratorium menggunakan axisymmetric dengan model Hardening Soil sedangkan Pemadatan Lapangan menggunakan Plane Strain dengan model Hardening Soil Small.

\subsubsection{Analisis dan Pembahasan}

Pemadatan Laboratorium akan menganalisis dan membahas mengenai hasil berat isi kering yang didapat dengan menggunakan numerik dan membahas mengenai penurunan dan variasi energi terhadap berat isi kering. Pemadatan lapangan akan membahas mengenai parameter seperti modulus elastisitas dan kohesi di setiap poisisi tebal lapis pemadatan serta jumlah lintasannya.

\subsubsection{Kesimpulan dan Saran}

Pemadatan laboratorium akan menyimpulkan tentang pengaruh variasi energi terhadap berat isi kering dan pemadatan lapangan akan menyimpulkan tentang pengaruh dari variasi beban dan tebal lapis pemadatan terhadap jumlah lintasan serta parameter di setiap posisi tebal lapis pemadatan

\subsection{Bagan Alir}

Untuk memberikan gambaran lebih jelas tentang tahapan penelitian yang dilakukan dalam tugas akhir ini maka dibuat bagan alir penelitian seperti pada Gambar $\mathbf{2}$.

\section{HASIL PENELITIAN DAN PEMBAHASAN}

\subsection{Pemadatan Laboratorium}

Pemadatan laboratorium yang berjenis modified proctor dengan menggunakan data proyek Jalan Tol Plumbon Cirebon yang ditunjukan pada Gambar 3. dan simulasi model pada Gambar 4.

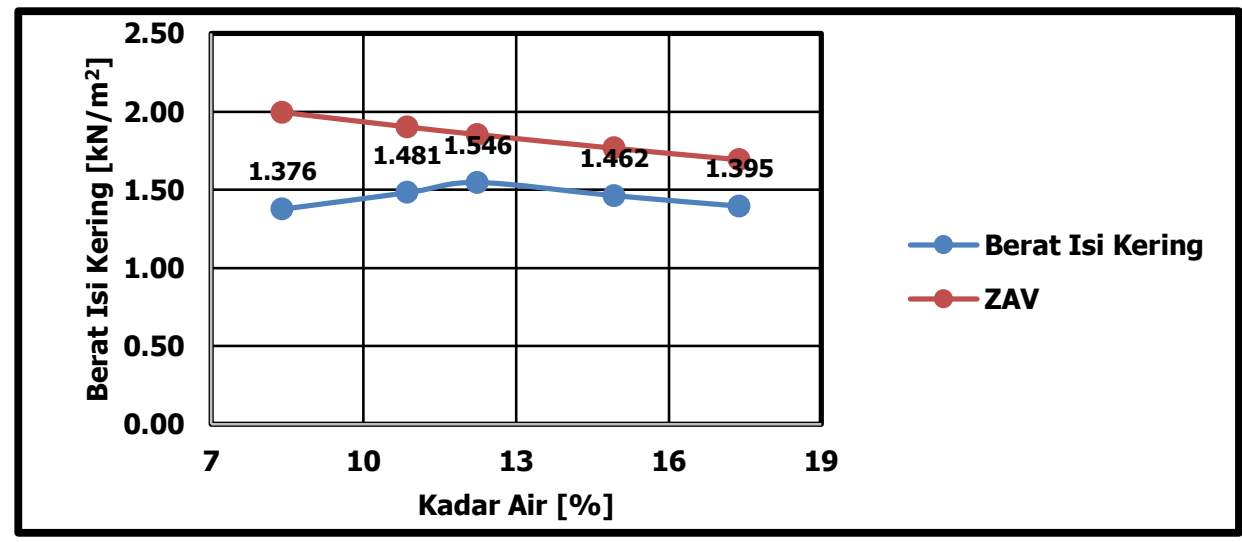

Gambar 3. Grafik hubungan antara kadar air dengan berat isi kering pada proyek jalan Tol Plumbon Cirebon 


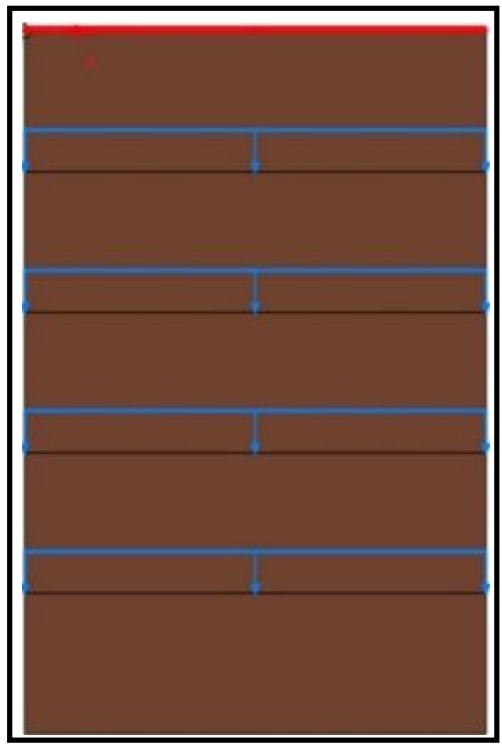

Gambar 4. Simulasi model pemadatan laboratorium

Adapun hasil grafik yang diperoleh dari analisis pemadatan laboratorium menggunakan PLAXIS 2D 2017 dapat dilihat pada Gambar 5, Gambar 6, Gambar 7, dan Gambar 8.

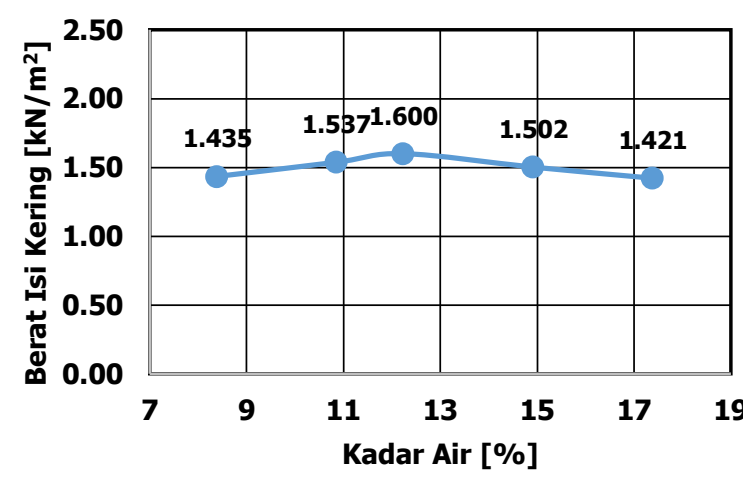

- Parameter $\mathrm{C}=19.3$ kPa, phi=4.997, dan $E=26000 \mathrm{kPa}$

Gambar 5. Grafik hubungan berat isi kering dengan kadar air kohesi 19,3 kPa

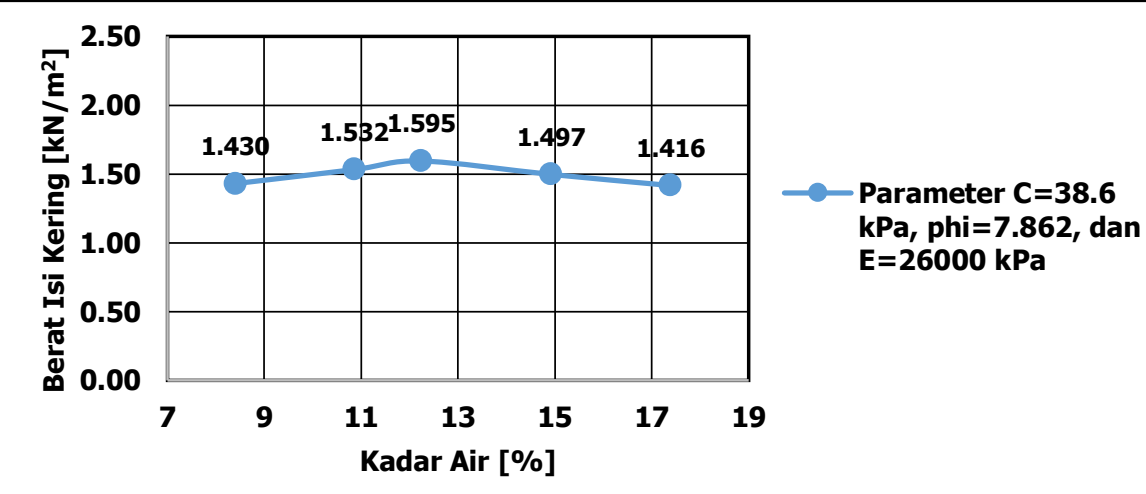

Gambar 6. Grafik hubungan berat isi kering dengan kadar air kohesi 38,6 kPa 


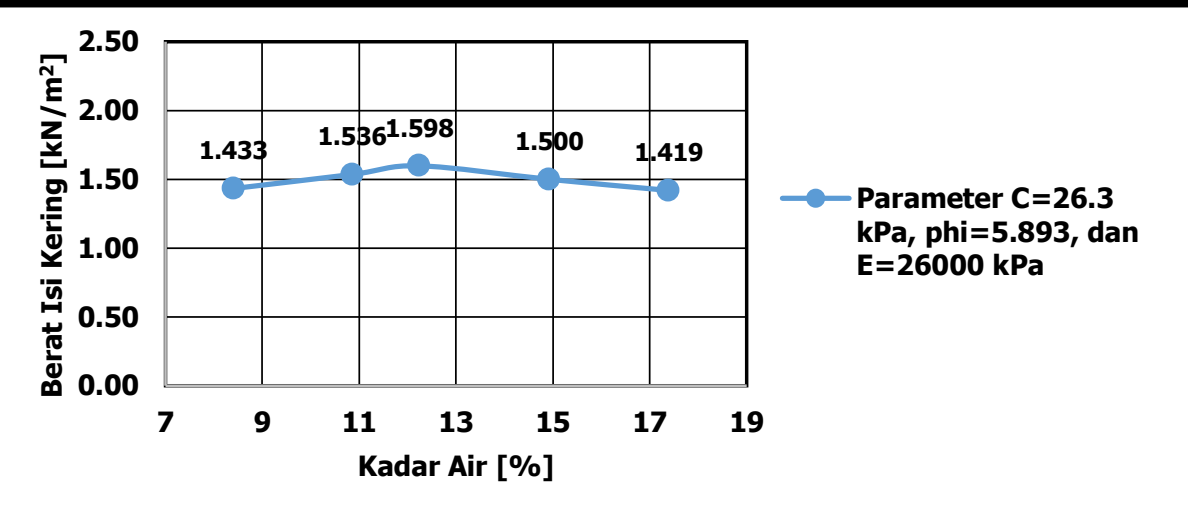

Gambar 7. Grafik hubungan berat isi kering dengan kadar air kohesi 26,3 kPa

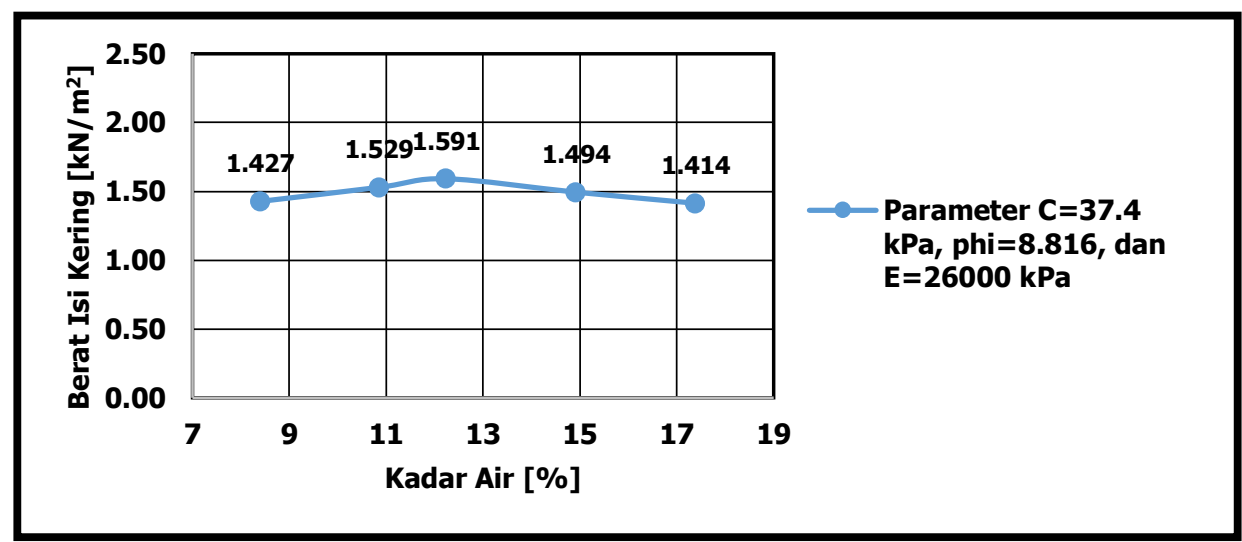

Gambar 8. Grafik hubungan berat isi kering dengan kadar air kohesi 37,4 kPa

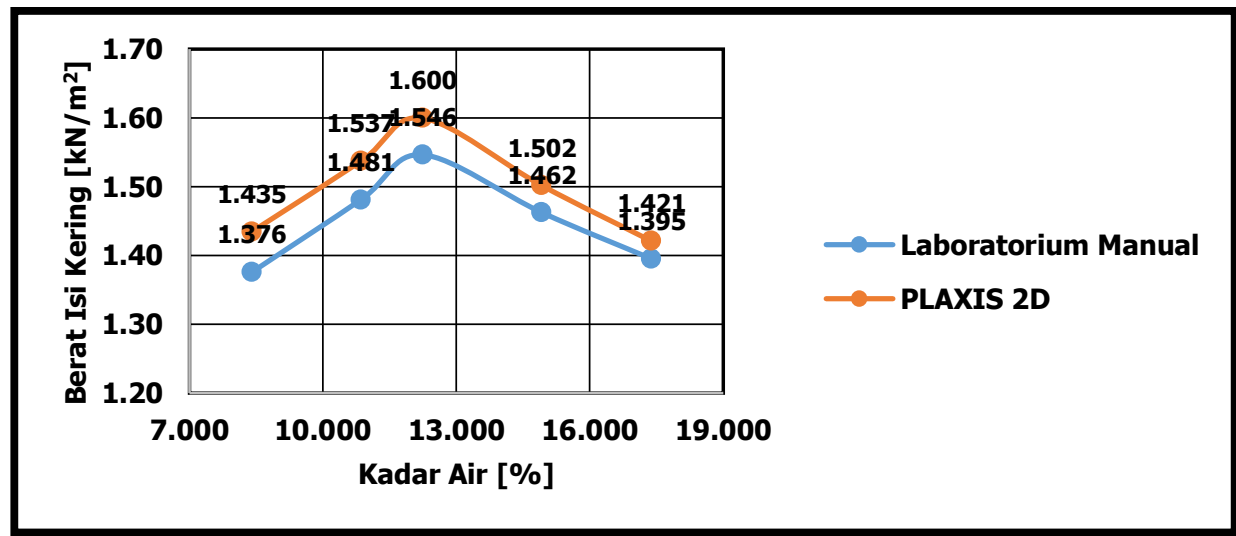

Gambar 9. Grafik hubungan berat isi kering dengan kadar air Proyek Jalan Tol Plumbon Cirebon antara laboratorium manual dengan PLAXIS 2D 2017

Hasil uji pemadatan berat isi kering di laboratorium sebesar 1,546 kN/m², sedangkan hasil simulasi model sebesar $1,6 \mathrm{kN} / \mathrm{m}^{2}$, sehingga tingkat akurasi perbedaannya sebesar $3,49 \%$ (Gambar 9). Adapun perbandingan hasil grafik yang diperoleh dari analisis pemadatan laboratorium menggunakan PLAXIS 2D 2017 dengan memvariasikan energi pemadatan didapt grafik yang ditunjukan pada Gambar 10. 


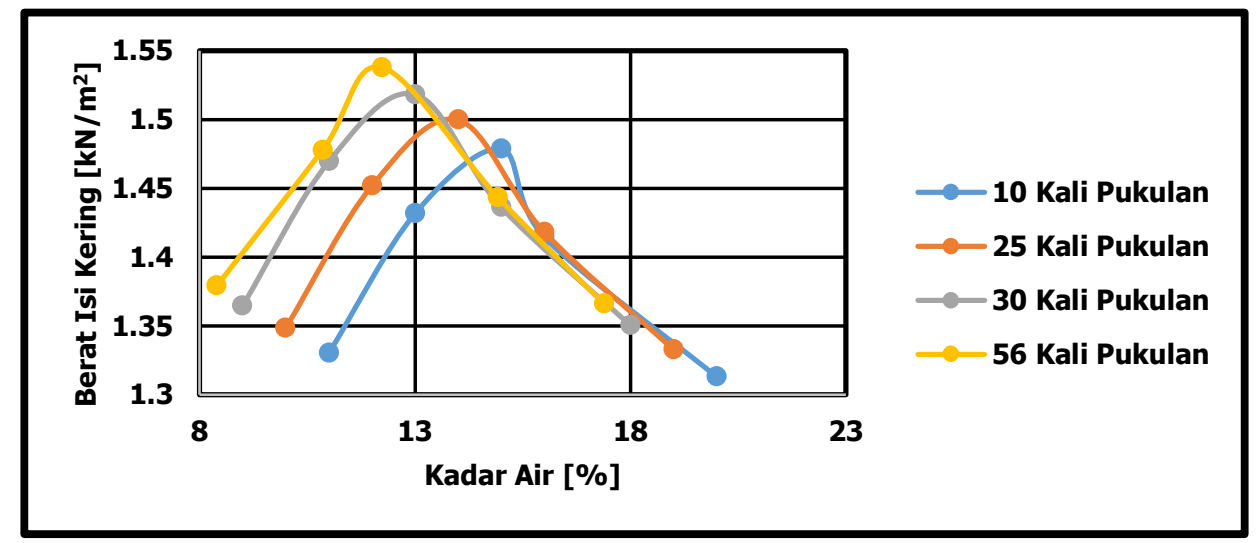

Gambar 10. Grafik hubungan kadar air dengan berat isi kering terhadap variasi energi pemadatan.

Modulus elastisitas atau kekakuan tanah merupakan nilai yang didapat dari pembagian antara tegangan dan regangan. Node strain yang dipilih memiliki posisi yang berbeda-beda, diantaranya atas, tengah dan bawah. Hasil dari tegangan regangan yang didapat tidak ada perbedaan yang besar, tetapi memiliki perubahan niai modulus elastisitas sebelum dan sesudah. Nilai modulus elastisitas setelah dipadatkan lebih besar dibandingkan dengan nilai modulus elastisitas sebelum dipadatkan disajikan pada Tabel 1.

Tabel 1. Nilai Modulus Elastisitas Setelah Dilakukan Pemadatan di PLAXIS 2D.

\begin{tabular}{ccccccc}
\hline Sample & $\begin{array}{c}\text { Tegangan 1 } \\
{\left[\mathbf{k N} / \mathbf{m}^{\mathbf{2}}\right]}\end{array}$ & $\begin{array}{c}\text { Regangan 1 } \\
{\left[\mathbf{k N} / \mathbf{m}^{\mathbf{2}}\right]}\end{array}$ & $\begin{array}{c}\text { Tegangan 2 } \\
{\left[\mathbf{k N} / \mathbf{m}^{\mathbf{2}}\right]}\end{array}$ & $\begin{array}{c}\text { Regangan 2 } \\
{\left[\mathbf{k N} / \mathbf{m}^{\mathbf{2}}\right]}\end{array}$ & $\begin{array}{c}\boldsymbol{E} \\
{\left[\mathbf{k N} / \mathbf{m}^{\mathbf{2}}\right]}\end{array}$ & $\begin{array}{c}\boldsymbol{E} \text { rata-rata } \\
{\left[\mathbf{k N} / \mathbf{m}^{\mathbf{2}}\right]}\end{array}$ \\
\hline $\mathbf{1}$ & $1.346,151$ & 0,001 & $2.713,662$ & 0,003 & $683.755,5$ & \\
\hline $\mathbf{2}$ & $1.346,297$ & 0,001 & $2.713,724$ & 0,003 & $683.713,5$ \\
\hline $\mathbf{3}$ & $1.367,477$ & 0,001 & $2.735,012$ & 0,003 & $683.767,5$ \\
\hline $\mathbf{4}$ & $1.346,675$ & 0,001 & $2.714,085$ & 0,003 & 683.705 & \\
\cline { 1 - 5 } & & & &
\end{tabular}

\subsection{Pemadatan Lapangan}

Pemadatan Lapangan merupakan pemadatan yang dilakukan dalam sekala besar yang mengacu pada pemadatan laboratorium. Berikut simulasi model pemadatan Lapangan yang ditunjukan pada Gambar 11.

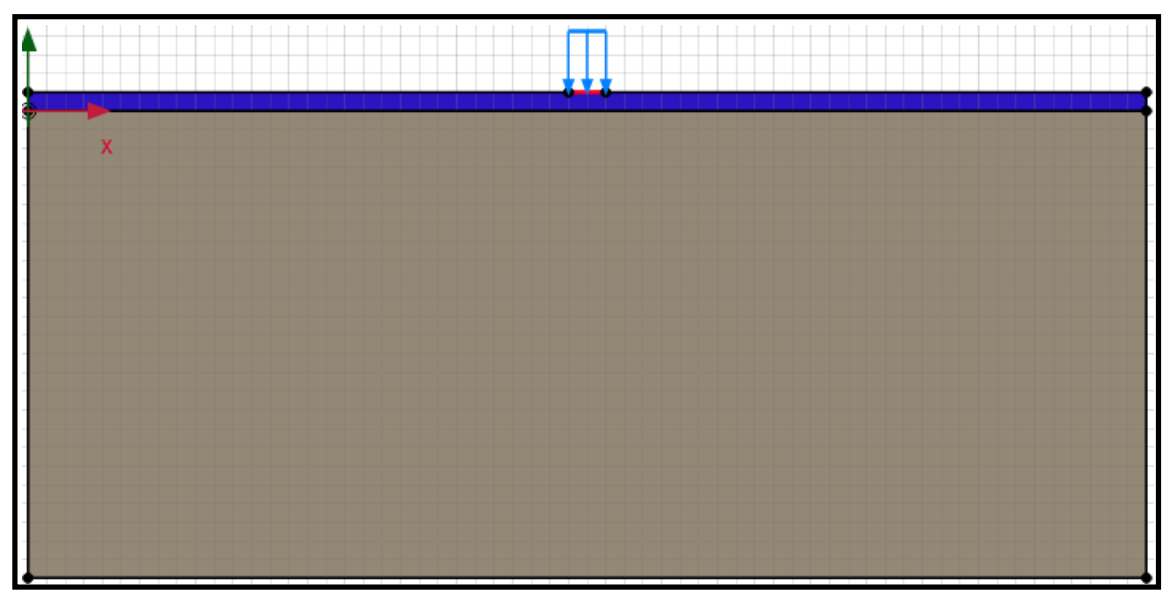

Gambar 11. Simulasi model pemadatan lapangan

Siklus yang didapat pada beban berat yaitu untuk tebal lapis $10 \mathrm{~cm}$ sebanyak 4 kali, tebal lapis $20 \mathrm{~cm}$ sebanyak 4 kali, tebal lapis $30 \mathrm{~cm}$ sebanyak 5 kali dan tebal lapis $100 \mathrm{~cm}$ sebanyak 9 
kali (Gambar 12). Siklus yang didapat pada beban sedang yaitu untuk tebal lapis $10 \mathrm{~cm}$ sebanyak 7 kali, tebal lapis $20 \mathrm{~cm}$ sebanyak 7 kali, tebal lapis $30 \mathrm{~cm}$ sebanyak 9 kali dan tebal lapis $100 \mathrm{~cm}$ sebanyak 11 kali (Gambar 13). Siklus yang didapat pada beban ringan yaitu untuk tebal lapis $10 \mathrm{~cm}$ sebanyak 12 kali, tebal lapis $20 \mathrm{~cm}$ sebanyak 16 kali, tebal lapis $30 \mathrm{~cm}$ sebanyak 21 kali dan tebal lapis $100 \mathrm{~cm}$ sebanyak 24 kali (Gambar 14) dan grafik hubungan antara penurunan dengan tebal lapis pemadatan ditunjukan pada Gambar 15.
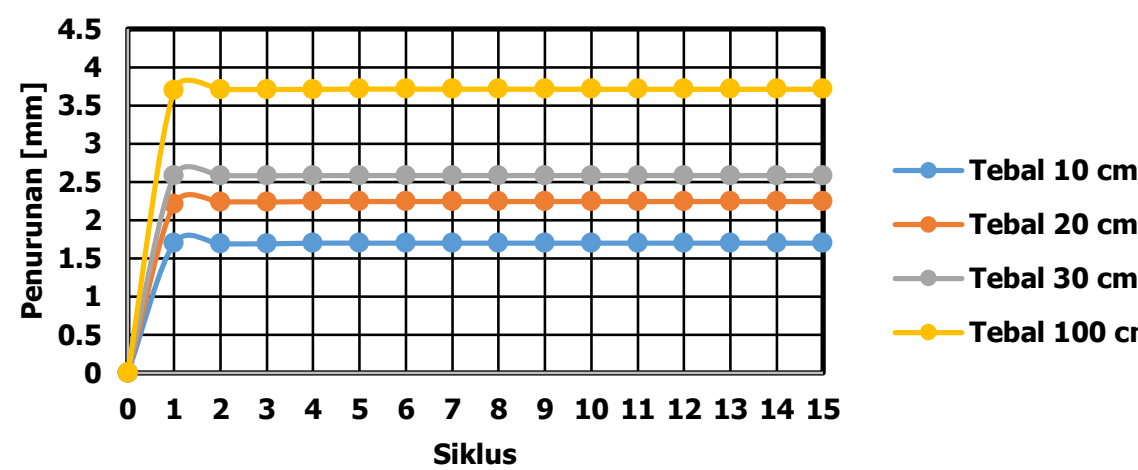

_ Tebal $20 \mathrm{~cm}$

- Tebal $30 \mathrm{~cm}$

- Tebal $100 \mathrm{~cm}$

Gambar 12. Hubungan antara siklus dengan penurunan untuk beban $35 \mathrm{kN} / \mathbf{m}^{2}$

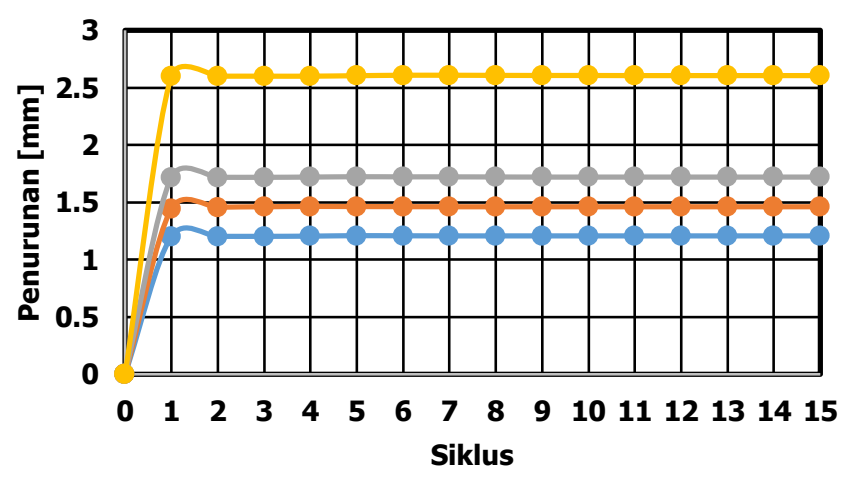

—- Tebal 10 m

—-Tebal $20 \mathrm{~cm}$

- Tebal 30 cm

Tebal $100 \mathrm{~cm}$

Gambar 13. Hubungan antara siklus dengan penurunan untuk beban $25 \mathrm{kN} / \mathrm{m}^{2}$

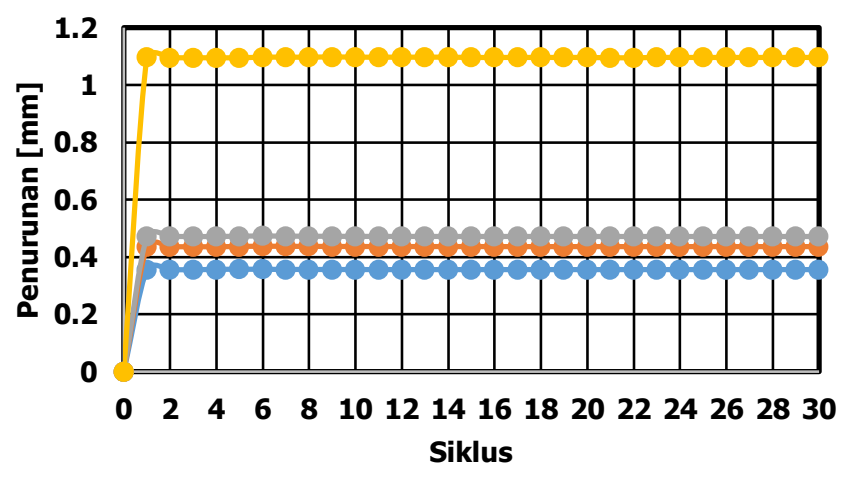

-Tebal $10 \mathrm{~cm}$

-Tebal $20 \mathrm{~cm}$

- Tebal $30 \mathrm{~cm}$

-Tebal $100 \mathrm{~cm}$

Siklus

Gambar 14. Hubungan antara siklus dengan penurunan untuk beban $10 \mathrm{kN} / \mathrm{m}^{2}$ 


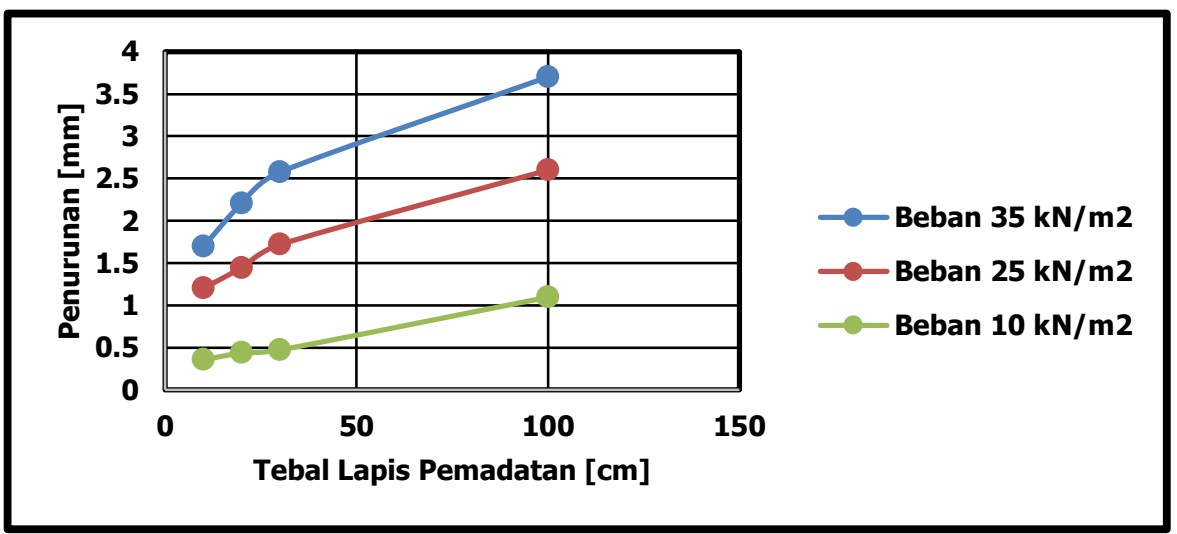

Gambar 15. Grafik hubungan antara penurunan dengan tebal lapis pemadatan

Hasil-hasil dari grafik diatas menunjukan bahwa semakin besar beban akan menghasilkan jumlah lintasan yang sedikit dengan ketebalan yang sama, dan semakin tebal suatu lapis pemadatan akan menghasilkan penurunan yang besar dengan beban yang sama.

Modulus elastisitas atau kekakuan tanah yang didapat dari pemadatan lapangan hampir sama dengan pemadatan laboratorium. Modulus elastisitas Posisi atas memiliki modulus yang paling besar jika dibandingkan dengan modulus tengah ataupun bawah.

Hasil modulus elastisitas dari pengaruh beban $35 \mathrm{kN} / \mathrm{m}^{2}, 25 \mathrm{kN} / \mathrm{m}^{2}$ dan $10 \mathrm{kN} / \mathrm{m}^{2}$ terhadap tebal lapis pemadatan $10 \mathrm{~cm}, 20 \mathrm{~cm}, 30 \mathrm{~cm}$, dan $100 \mathrm{~cm}$ yang disajikan pada Tabel 5 .

Tabel 2. Hasil Modulus Elastisitas dari Pengaruh Beban $35 \mathrm{kN} / \mathrm{m}^{2}, 25 \mathrm{kN} / \mathrm{m}^{2}$ dan $10 \mathrm{kN} / \mathrm{m}^{2}$ Terhadap Tebal Lapis Pemadatan.

\begin{tabular}{ccccc}
\hline \multirow{2}{*}{ Tebal Lapis Pemadatan $[\mathbf{c m}]$} & \multicolumn{3}{c}{ Nilai $\boldsymbol{E}\left[\mathbf{k N} / \mathbf{m}^{\mathbf{2}}\right] \mathbf{u n t u k}$ Beban $\left[\mathbf{k N} / \mathbf{m}^{\mathbf{2}}\right]$} \\
\cline { 2 - 5 } & & $\mathbf{3 5}$ & $\mathbf{2 5}$ & $\mathbf{1 0}$ \\
\hline \multirow{2}{*}{10} & Atas & $869.524,133$ & $612.713,534$ & $899.675,274$ \\
\cline { 2 - 5 } & Tengah & $471.201,168$ & $40.749,106$ & $519.528,857$ \\
\cline { 2 - 5 } 20 & Bawah & $157.638,262$ & $204.88,365$ & $160.411,297$ \\
\cline { 2 - 5 } & Atas & $443.255,645$ & $344.955,213$ & $313.798,352$ \\
\cline { 2 - 5 } & Tengah & $145.876,300$ & $171.946,213$ & $147.056,698$ \\
\hline \multirow{2}{*}{30} & Bawah & $761.44,092$ & $60.065,872$ & $76.548,832$ \\
\cline { 2 - 5 } & Atas & $346.703,487$ & $446.098,772$ & $345.543,725$ \\
\hline \multirow{2}{*}{100} & Tengah & $59.193,148$ & $146.744,388$ & $58.855,472$ \\
\hline & Bawah & $59.602,878$ & $76.485,026$ & $59.903,323$ \\
\hline & Atas & $624.180,926$ & $889.074,609$ & $601.602,399$ \\
\hline & Tengah & $77.493,163$ & $485.430,534$ & $54.112,307$ \\
\hline & Bawah & $50.572,786$ & $159.982,799$ & $50.129,327$ \\
\hline
\end{tabular}

\section{KESIMPULAN}

\subsection{Pemadatan Laboratorium}

Berdasarkan analisis dan pembahasan tentang pemadatan laboratorium maka dapat dibuat perihal kesimpulan yang dapat diuraikan sebagai berikut:

1. Pemadatan laboratorium dengan menggunakan pendekatan numerik memiliki hasil berat isi kering yang hampir sama dengan pemadatan laboratorium pada proyek Jalan Tol Plumbon Cirebon. 
2. Grafik hubungan antara kadar air dengan berat isi kering dengan menggunakan evaluasi numerik secara garis besar mendekati jika dibandingkan dengan hasil pemadatan laboratorium pada Proyek Jalan Tol Plumbon Cirebon.

3. Parameter yang dipakai pada pemadatan laboratorium dengan evaluasi numerik akan lebih akurat jika parameternya sama dengan parameter pada Proyek Jalan Tol Plumbon Cirebon (tidak memakai pendekatan).

4. Perbedaan berat isi kering yang terjadi pada pemadatan laboratorium dengan simulasi pemadatan laboratorium karena pemadatan laboratorium dipengaruhi oleh faktor mold yang jelek, tinggi jatuh yang tidak sesuai (human error), dan penguapan yang terjadi pada tanah.

5. Semakin besar energi pemdatan yang digunakan maka semakin besar berat isi keringnya, karena udara yang ada pada tanah lebih kecil jika dibandingkan dengan energi pemadatan yang kecil.

6. Hasil pemadatan berat isi kering di laboratorium dengan simulasi model memiliki tingkat akurasi perbedaan sebesar 3,5\%.

\subsection{Pemadatan Lapangan}

Beradasarkan analisis dan pembahasan tentang pemadatan lapangan maka dapat dibuat perihal kesimpulan yang dapat diuraikan sebagai berikut:

1. Semakin besar beban, siklus dan tebal lapis pemadatan yang diberikan pada proses pemadatan maka semakin besar penurunannya.

2. Beban berat memiliki jumlah lintasan yang besar, dibandingkan dengan beban sedang maupun beban ringan.

3. Semakin besar beban maka jumlah lintasan yang didapat akan semakin kecil, karena pada saat tertentu akan mendapatkan penurunan yang tidak akan terjadi penurunan lagi (konstan).

4. Untuk tebal lapis pemadatan yang tebal direkomendasikan menggunakan alat penggilas yang besar, sedangkan untuk tebal lapis pemadatan yang kecil direkomendasikan menggunakan alat berat yang sedang dan tebal lapis pemadatan yang sedang, direkomendasikan menggunakan alat berat yang sedang.

5. Tebal lapis pemadatan yang ideal sebesar $20 \mathrm{~cm}$ dan $30 \mathrm{~cm}$ efisien jika digunakan menggunakan beban sedang sebesar $25 \mathrm{kN} / \mathrm{m}^{2}$.

6. Posisi atas pada suatu tebal lapis pemadatan akan mendapatkan modulus elastisitas yang besar karena posisi atas dekat dengan beban pemadatan.

7. Model Hardening Soil Small cocok pada penurunan yang relatif kecil.

\section{DAFTAR RUJUKAN}

Howeedy, M. F. (1975). Factors Influencing Vibratory Compaction of Cohesionless Soils. 54 Annual Meeting of the Transportation Research Board. 548, pp. 88-96. Washington DC: Transportation Research Board.

Proctor, R. R. (1933). Fundamental Principles of Soil Compaction. Engineering News Record, 111(_), 286.

Seligh, E. T. (1997). Fundamentals of Vibratory Roller Behaviour. Proc., $9^{\text {th }}$ International Conference on Soil Mechanics and Foundation Engineering. Tokyo.

Shanz, T. (1998). Zur Modellierung des Mechanisen Verhaltens von Reibyngsmaterialen, Habilitation. Germany: Stuttgard University.

Wesley, L. (1977). Mekanika Tanah. Jakarta: Pekerjaan Umum. 